DOI: https://doi.org/10.47405/mjssh.v6i4.749

\begin{tabular}{|c|c|}
\hline 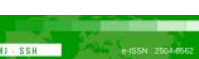 & Malaysian Journal of Social Sciences and Humanities (MJSSH) \\
\hline Malaysian Journal of & Volume 6, Issue 4, April 2021 \\
\hline (mu-ssh) & e-ISSN : 2504-8562 \\
\hline & $\begin{array}{l}\text { Journal home page: } \\
\text { www.msocialsciences.com }\end{array}$ \\
\hline
\end{tabular}

\title{
Systematic Review: Challenges in Teaching Writing Skills for Upper Secondary in ESL Classrooms and Suggestions to overcome them
}

\author{
Saravanan A/L Palanisamy ${ }^{1}$, Azlina Abdul Aziz ${ }^{1}$ \\ ${ }^{1}$ Faculty of Education, Universiti Kebangsaan Malaysia (UKM) \\ Correspondence: Saravanan A/L Palanisamy (sararaj5@yahoo.com)
}

\begin{abstract}
This paper presents a systematic review of relevant published studies on challenges in teaching writing skills for upper secondary in ESL classrooms and solutions to overcome them from year 2012-2020. This systematic review attempts to address two research questions; i.e. what are the writing challenges of the students and what are the solutions to overcome writing challenges faced by ESL students. 12 single studies and 2 systematic reviews were systematically reviewed and revealed that the most challenges encountered by students in writing are word choice, vocabulary, grammar and poor organisation of ideas. The findings also shed some lights on solutions to overcome the challenges from teachers' and students' perspective. Teachers should act as a guidance by providing sample essays, giving feedbacks and choose suitable approach by identifying students' needs. Meanwhile the students should read more to generate ideas and improve their vocabulary and grammar knowledge.
\end{abstract}

Keywords: systematic review, writing challenges, writing skills, ESL classrooms, writing strategies

\section{Introduction}

English is a lingua franca which is regarded as international language is important for the purpose of communication, education, and business. English language has become one of the vital languages in our country. English Language is the second language in our country. The teaching and learning of English has four main skills and they are reading, writing, listening and speaking.

Writing skill is a major component in English language learning. Giridharan and Robson (2011) states that writing skills should be developed through formal instructional situations. Meanwhile according to Ling (2016), writing is a multiplex activity. This skill needs to be taught since primary school in order for the students to be creative and produce good pieces of writing in the future. Therefore, ESL learners need to equip themselves with better writing skills. They will get more opportunities in the working field once they have completed their studies at tertiary level. Business world needs future employers prepared with effective writing skills who are seen as the clients of corporate field (Zhu, 2014). This, in other words means that good writing skills assist them to get engaged to the world around them and acts as a gateway to receive the needed knowledge from all aspects. Thus, writing is a vital skill from all the aspects in the professional field.

The major concern that has been important is that although writing skill plays the role of the main skill in the academic sector, several prior researches conducted have concluded that it is not encouraged and not effective as expected among the students. As we know, even though it is viewed that English 
instruction has been compulsory in the Malaysian education system, but the implementation is insufficient as the concentration is only upon the language structure formed by the students. The profound writing skills have not really been established well among the students. In other words, the syllabus and teaching methods are inadequate in terms of covering the obstacles that the students need to face in writing.

This clearly shows a scenario where Malaysia students are unable to express their ideas clearly and creatively during the teaching and learning session. Students will face challenges if they do not practice writing skill when they further their tertiary education. According to Mahboob (2014), ESL learners need to be equipped with this language skill because it is used extensively for global mediation of knowledge. In simpler words, they will gain autonomy by becoming efficient writers and achieve more than required knowledge in all fields.

According to Nunan (1999), producing a coherent, fluent and extended piece of writing is the most difficult task to attempt in language learning. Hyland (2008) states that writing is considered as a complex cognitive task consisting a number of processes and strategies. It can be seen that writing skill is not an easy skill to master for ESL students. It is very important for communication purposes which creates a channel between the writer and the reader. Thus, writing is seen as the master of all language skills because without it, one is considered has no intelligence and blind in knowledge.

Hence, analyses and researches have been carried out on writing problems among students in the other countries such as Indonesia, Thailand, and Vietnam who learn English as Foreign Language (EFL). The results have proven that the students seldom write and are given the best solutions as intervention practices for them to overcome this issue. Nevertheless, limited studies have been conducted on students in Malaysia related to writing skills related to improving writing, attitudes and motivation in learning writing skills and the process of learning writing skill itself but not specifically on writing challenges in general. Thus, this research is planned to be conducted on the upper secondary school students to know the problems and challenges they face in writing skills.

Mohtar et. al., 2017 found that students often show weaknesses in their written work especially structures they produced and also the ideas they are trying to express. Teachers give minimal guidance to their students on writing strategies because teachers do not understand the problems faced by their students (Maarof and Murat, 2013). In order to tackle the challenges students face in writing, teachers should understand the problems the students are facing. It is important to view the strategies employed by the teachers in teaching writing so that this skill can be developed further.

\section{Literature Review}

\section{Definition of Writing}

Writing is a way to deliver ideas, experiences and feeling into written form. Nunan (1989) states that writing is not a natural activity. Ordinary individuals learn to speak the language. Meanwhile, according to Finocchiaro (1974), ESL learners should be inspired to convey their ideas, experiences, thoughts and feeling. In addition, Asmuti (2002), explains that writers have the opportunity to elaborate their ideas in an organised manner by mastering the writing skill. It is vital for a learner to learn a language by including more vocabulary, idioms and more grammatical structure (Zulfani, 2001).

\section{Writing in an ESL Context}

Brown (2007) proclaims that writing is a thinking process which can be planned and revised numerous times before getting the end product. Meanwhile Harmer (2004) further adds that students are encouraged to pay more attention to accurate language use in writing. This is because when students are involved in writing activity, they will consider how a language is used. It is believed that the language development of the students will be triggered because the students themselves will resolve the problems that writing 
puts in their mind. Troyka (2010) proposes that the purposes of writing enables the writers to express themselves, deliver information, convince readers and create literary work. Messages on a specific topic or subject are delivered to others through writing. To strengthen this view, Brereton (1995) adds that there are three vital elements in the context of writing which are the text or message, the writer and the reader. Tierney et. al., (1989) claims that writing skill is a complex cognitive skill because it involves the students to use appropriate intellectual skills, cognitive strategies, verbal information, language rules and motivation. Starkey (2004) adds that writing in English within the academic context needs some criteria of acceptability relative to different features of writing that comprise organization, vocabulary, language use, punctuation, correct capitalization and paragraphing.

\section{Approaches to Writing}

Various approaches blended with strategies are essential in teaching of writing (Selvaraj \& Aziz, 2019). According to Lavelle and Bushrow (2017), writing approach is described through the connection among the views the writers have on writing and the patterns of writing approaches that they use. To sum up, ideas, rules and ethics associated with writing process employed in the classrooms during writing lessons are writing approaches.

\section{Product Approach}

The product approach to writing focuses not on the process but on the finished results of the writing job. According to Nunan (1989) notes that the product approach to writing focuses on the final result of the compositional act, that is to say the text, essay plot, etc. In this approach, the teacher's main concern is the end product which is readable, grammatically correct and follows discourse conventions such as main points and supporting details. Priority is given to formal accuracy and grammar, spelling and vocabulary. Getnet (1994:9) states that product approach is an orientation whose primary focus is the end result of what students produce. This approach is also known as "a traditional approach in which students are encouraged to mimic a model text, usually is presented and analysed at an early stage" (Gabrielatos, 2002, p.5)

According to Steel (2004) there are mainly four steps the students need to follow in ESL writing class. First, students are required to read sample essays and pay attention to the unique characteristics of an essay such as how the ideas are organised, the language use and also mechanics of writing. The second step is students practise the features they have identified in the model essays in isolation. The third step is the most important steps where the students try to copy the model essays by organising ideas to suit the model. During this step, how ideas are organised is given more importance than the ideas themselves. The last step is students try compose their own essay by using their skills, sentence structures and a variety of vocabulary. Raimes (1983:6) clarifies that this approach is 'in the control' approach of teaching writing where students are given sentences to copy and manipulate with very minimal chances of committing errors. This approach is beneficial when students attempt narrative, descriptive and persuasive essays because the students will start learning how to use specific pattern-product methods in writing essays. Another advantage of this approach according to Tangpermpoon (2008), students will improve their grammatical awareness and they learn to correct vocabulary and a variety of sentence structures in essays. This approach is not popular because it only focuses on grammar structure and syntax not the process of writing. This cause the students to be demotivated.

\section{Process Approach}

According to Kroll (2001) process writing is an umbrella term for various writing courses. According to him, writing is a cyclical approach rather than single-shot approach. Students will go through few stages of writing process before producing complete writing task. They can always review and revise their written work. There are four stages of writing in this approach, mainly, planning, drafting, revising and editing. In this approach, various classroom activities are given more attention to encourage the development and use of language such as brainstorming, rewriting and group discussion. 
Meanwhile, Steele (2004) states that there are 8 stages in this approach. Stage one is brainstorming which is generating ideas through discussion. Stage two is planning where students exchange ideas in note form. Meanwhile stage three is mind mapping. In this stage, students organize ideas into graphic organisers. Stage four is writing the first draft which is done frequently in class in pairs or groups. Stage five is peer feedback. In this stage, students exchange drafts where they edit each other's work. Stage six is editing. During this stage, upon receiving peer feedback on the drafts, improvements are made. Stage seven is the final written draft. Stage eight which is the last stage is evaluation and teachers feedback where the writings are evaluated and feedback is given by teachers.

On the other hand, Edwin et al. (1996) proposes that there are six stages of writing process which are determining the topic, taking account of readers, editing, proof reading and revising. In process approach, writing is regarded as complex, cognitive, recursive and evolving process. This approach promotes the students to write freely to improve their writing. The students' creativity are encouraged while undergoing the process approach. Students can always improve their writing abilities in ESL classrooms because scaffolding happens. Students become better writer as they have the opportunity to revise the feedbacks given by their teachers and peers. Maarof et. Al. (2011, p.30) states that the main requirement for students to improve their writing is feedback from the teacher. The drawback of this approach is it is time-consuming and it pays great attention to the process not the structures and grammar. According to Gao (2007), this approach does not focus on the variety and differentiation of the process of writing, specifically social context.

\section{Genre Approach}

This approach is regarded as one of the key approach in writing. This approach pays great attention to a variety of writing types and texts and intertwined with social needs. It also has a specific purpose in a specific context using appropriate conventions. The fundamental spirit behind this approach is writers do not write for pleasure but in different contexts (Farooq et. al., 2012). In this approach, students learn different types of sentence structures for different text types. Elashri 2013, p.7) elaborates that learners develop their ability to compose a specific genre if learners are exposed to a variety of examples of the same genre. Anxiety among learners can be reduced among beginners because model text is given to help in their learning process. Most importantly, this approach promotes scaffolding. However the drawbacks of this approach according to Palttridge (2004), mixing of textual and socio-cultural information makes the identification of the exact knowledge a difficult job.

\section{Eclectic Approach}

Eclectic approach is combination of genre and process approach. This approach is getting popular because of it is effective in teaching writing skills (Badger \& White, 2000). This approach is also believed to be beneficial for teachers and students in acquiring writing skills as it gives opportunity for the students to develop their creativity. This approach helps students to understand the features of target genre which enhances learners' proficiency because they get the knowledge on form and language at the same time and its function at the same time.

As conclusion for writing approaches in ESL classrooms, there is a common disagreement regarding these approaches where there is no single approach that can improve writing proficiency of learners. According to Anwar \& Nazir (2016), different approaches suit to different contexts. Meanwhile, Nordin (2017) also agrees that there is no specific approach that suits ESL students. Furthermore, he adds that in teaching writing skills, process and genre approach complements each other.

\section{Challenges in Writing}

Writing is always seen as a challenge for a student in acquiring the skill. According to Heaton (1975) writing skill is complex and not easy to be taught. Writing skill does not require mastery in grammatical and rhetorical devices only but also the elements of conceptual and judgemental. Students 'lack of certain skill such as proper use of grammar, conventions, punctuation, capitalization and spelling' 
(Ghaboo et. al. 2012, p.130; Ramasamy \& Abdul Aziz, 2018, p.2266). In addition, Foroutan et. al. (2013) addressed that ESL learners are struggling vocabulary, language use and sentence formation. They make errors in terms of grammar, sentence structures, tenses and spelling.

Misbah et. al., (2017) states that students cannot acquire writing skills because they lack of vocabulary. Asep (2014) agrees that vocabulary is the basic element in making sentences which is the fundamental of effective writing skills. Students communicate their ideas through words used every day in spoken and written. Furthermore, grammar plays a vital part in writing. It gives information which help the readers to comprehend its meaning. With little knowledge in grammar, students will face difficulty in writing correct sentences. Muhammad Fareeth et. al. (2016) points out that preposition, subject-verb agreement, tenses, pronouns, articles, and basic sentence structures are common mistakes done by students.

Meanwhile, Nyangau Benard (2014) proposed that poor spelling is another challenge students face in acquiring writing skills. He further claimed that students are not improving because they are struggling with correct spelling which is a fundamental element is writing. Afrin (2012) stated that students will exclude or include extra letters in their spellings if ESL students are not aware of the correct spelling. The students spell the words according to their pronunciation which causes wrong spelling. Jayousi (2011) argued that irregularities in English spelling system are the core reason for spelling errors. This has caused difficulty for the students to memorise.

Maros et. al. (2007), cited in Musa et. al (2012) stated that while investigating students language learning challenges, L1 interference especially Bahasa Melayu is hindering the achievement of English literacy among Malaysian ESL secondary students. In their research, error and contrastive analyses examining most of the writing error types among 120 Malaysian students showed that grammar is another challenge in acquiring the writing skill. It is concluded that the grammar errors made are caused by L1 interference. ESL students are facing with anxiety when they cannot write a grammatically correct sentence structures. Myles (2002) stated that students have the tendency to translate from their first language while writing. In addition, Friedlander (1990) as cited in Myles (2002) argued that students also use first language when generating ideas and attending to details.

\section{Methodology}

The method involves the main strategy which is challenges faced by ESL students in writing. The first step is the planning of the review that was carried out to identify the need of the review. The second step is conducting the review to recognise relevant researches that explored the challenges and difficulties faced by ESL students in writing. The third step is carrying out to report the review by communicating the results. The materials for this review were downloaded from online bibliographic databases such as Google Scholar, Science Direct, JSTOR, Springer e-journals, ProQuest Education Journals, SAGE, Scopus, and Educational Resources Information Centre (ERIC). These materials were used to identify peer-reviewed research articles or studies written in English published between 2012- 2020. The combination of terms used to search for the past related studies in the keywords fields of the above databases were: (writing challenges) or (writing difficulties) and (ESL learners or ESL classrooms). The title and abstract of the researches were vetted with regard to the inclusion criteria as following:

i. The respondents or participants involved in the research could be at their primary, secondary or tertiary level.

ii. These researches should be carried out in teaching English as second language (ESL).

iii. The researches should emphasis on writing challenges in ESL context.

iv. English language must be used with writing.

v. The research could employ qualitative, quantitative, or mixed-method research designs as more methodologically rigorous studies are needed. 
DOI: https://doi.org/10.47405/mjssh.v6i4.749

Nevertheless, it is difficult to disregard journals or articles based on the title and abstract of the researches solely. Hence, the introduction and conclusion sections of the full article were read through in order a wider range of researches could be chosen and fourteen articles were shortlisted.

\section{Result}

A total of two systematic reviews and twelve past related research from 2012 to 2020 on challenges and difficulties faced by ESL learners in writing were identified by following the procedures of conducting a systematic review were shortlisted. The findings are organised in Table 1,2 and 3.

Table 1: Summary of studies on writing challenges in ESL classrooms

\begin{tabular}{|c|c|c|c|}
\hline Article/ Study & $\begin{array}{l}\text { Number of } \\
\text { Participants/ } \\
\text { Studies/ } \\
\text { Research } \\
\text { Design }\end{array}$ & Results & $\begin{array}{c}\text { Strategies found } \\
\text { effective / Suggestions / } \\
\text { Recommendation }\end{array}$ \\
\hline $\begin{array}{l}\text { Ghabool, Mariadass } \\
\text { \& Kashef (2012) }\end{array}$ & 30 ESL students & $\begin{array}{l}\text { Malaysian ESL students } \\
\text { have problems in writing } \\
\text { tasks, especially in } \\
\text { language use (grammar) } \\
\text { and punctuation, and first } \\
\text { language interference. } \\
\text { More practices in writing } \\
\text { classes should be given. }\end{array}$ & $\begin{array}{l}\text { The use of punctuation } \\
\text { marks should be } \\
\text { explained and more } \\
\text { training on writing } \\
\text { conventions should be } \\
\text { given }\end{array}$ \\
\hline $\begin{array}{l}\text { Farooq, Uzair-Ul- } \\
\text { Hassan \& Wahid } \\
(2012)\end{array}$ & $\begin{array}{l}245 \\
\text { College } \\
\text { students } \\
\text { Survey }\end{array}$ & $\begin{array}{l}\text { Students face problems } \\
\text { due to lack of vocabulary, } \\
\text { spelling, L1 interference, } \\
\text { poor understanding of } \\
\text { grammatical structure. }\end{array}$ & $\begin{array}{l}\text { Teachers should adopt } \\
\text { eclectic approach and } \\
\text { teach vocabulary } \\
\text { innovatively. Spelling } \\
\text { activities should be given. } \\
\text { More emphasis on } \\
\text { grammar and written } \\
\text { work than oral activity } \\
\text { during English lesson }\end{array}$ \\
\hline $\begin{array}{l}\text { Whai, Wei \& Man } \\
\text { (2013) }\end{array}$ & $\begin{array}{l}132 \text { poly } \\
\text { students } \\
\text { Questionnaires }\end{array}$ & $\begin{array}{l}\text { Students face major } \\
\text { difficulties in creativity } \\
\text { and critical thinking, } \\
\text { proofreading, } \\
\text { grammatical sentences, } \\
\text { L1 interference, tenses } \\
\text { and vocabulary }\end{array}$ & $\begin{array}{l}\text { Extensive reading is } \\
\text { needed to improve } \\
\text { writing. More writing } \\
\text { practices should be given. } \\
\text { Different platforms can be } \\
\text { used to encourage writing } \\
\text { habit. }\end{array}$ \\
\hline $\begin{array}{l}\text { Whai \& Yahya } \\
\text { (2013) }\end{array}$ & $\begin{array}{c}60 \\
\text { Post-graduate } \\
\text { TESOL students }\end{array}$ & $\begin{array}{l}\text { The study reveals that the } \\
\text { students face problems in } \\
\text { relation to comprehension } \\
\text { and conception of an idea, } \\
\text { mechanics, composition, } \\
\text { language accuracy, } \\
\text { appropriate language and } \\
\text { vocabulary. }\end{array}$ & $\begin{array}{l}\text { Reading extensively } \\
\text { improve writing skill. } \\
\text { Guidance from the } \\
\text { teachers on writing by } \\
\text { giving feedbacks - } \\
\text { feedback on form and } \\
\text { feedback on content. Peer } \\
\text { review should be carried } \\
\text { out in classrooms. }\end{array}$ \\
\hline IM Alfaki (2015) & $\begin{array}{l}20 \text { university } \\
\text { students } \\
\text { Descriptive } \\
\text { research }\end{array}$ & $\begin{array}{l}\text { Students have various } \\
\text { writing problems - } \\
\text { morphology, syntax, } \\
\text { usage errors, mechanical } \\
\text { mistakes - spelling, }\end{array}$ & $\begin{array}{l}\text { Reading helps to increase } \\
\text { knowledge on vocabulary, } \\
\text { grammatical structures. } \\
\text { Giving free writing } \\
\text { practice. Note taking is }\end{array}$ \\
\hline
\end{tabular}




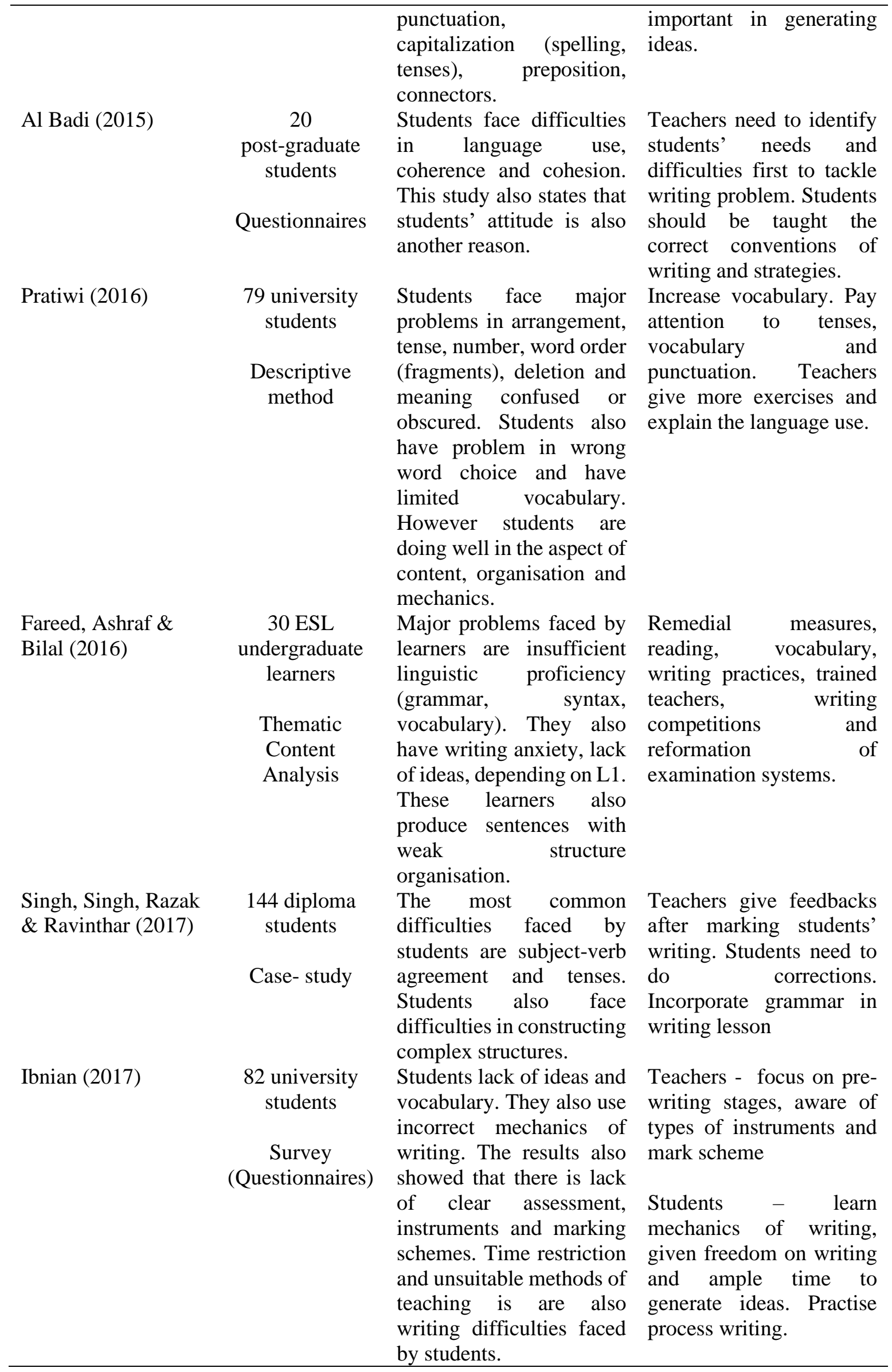


DOI: https://doi.org/10.47405/mjssh.v6i4.749

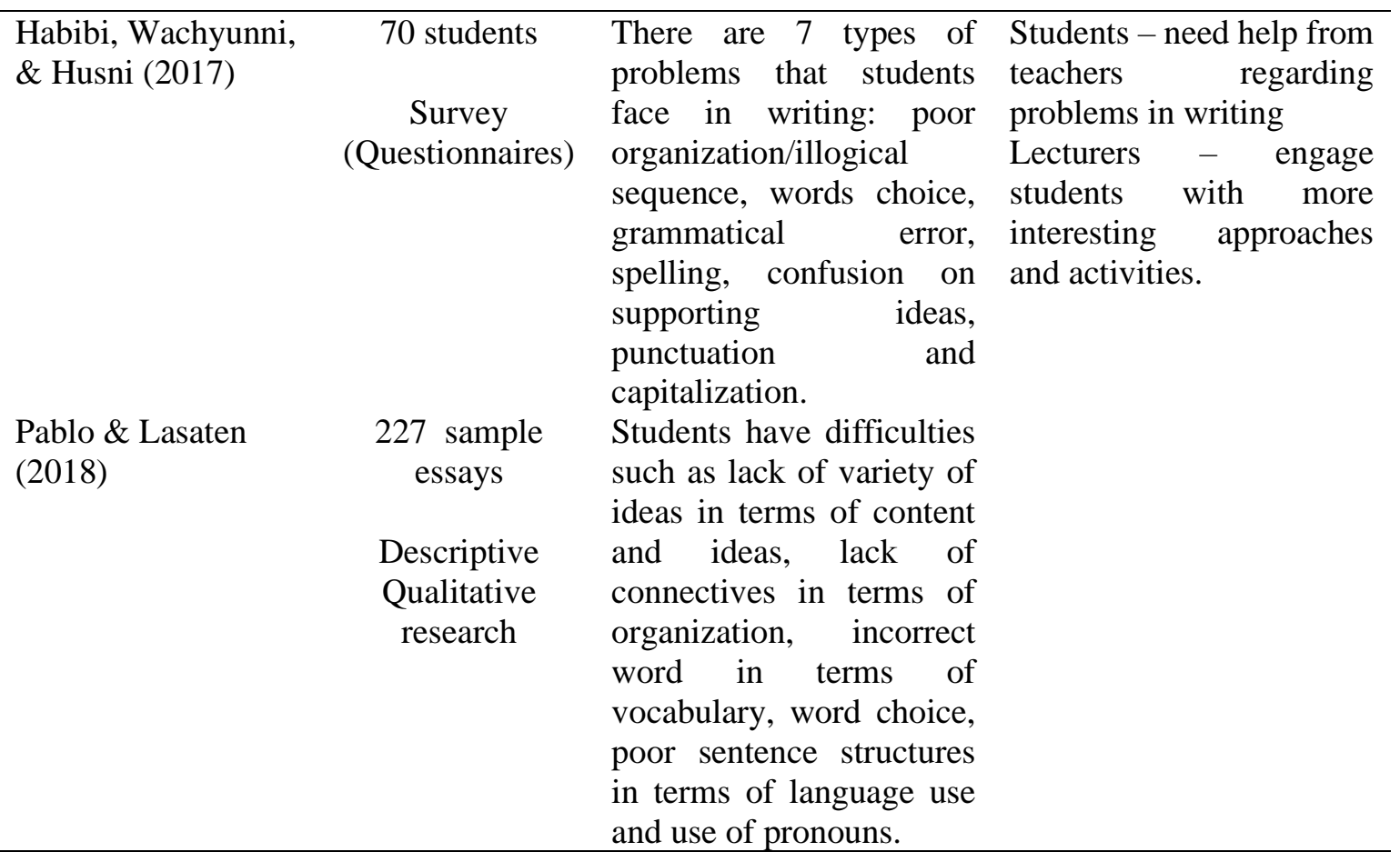

Table 2: Summary of systematic reviews on Challenges and Solutions on ESL Students' Academic Writing

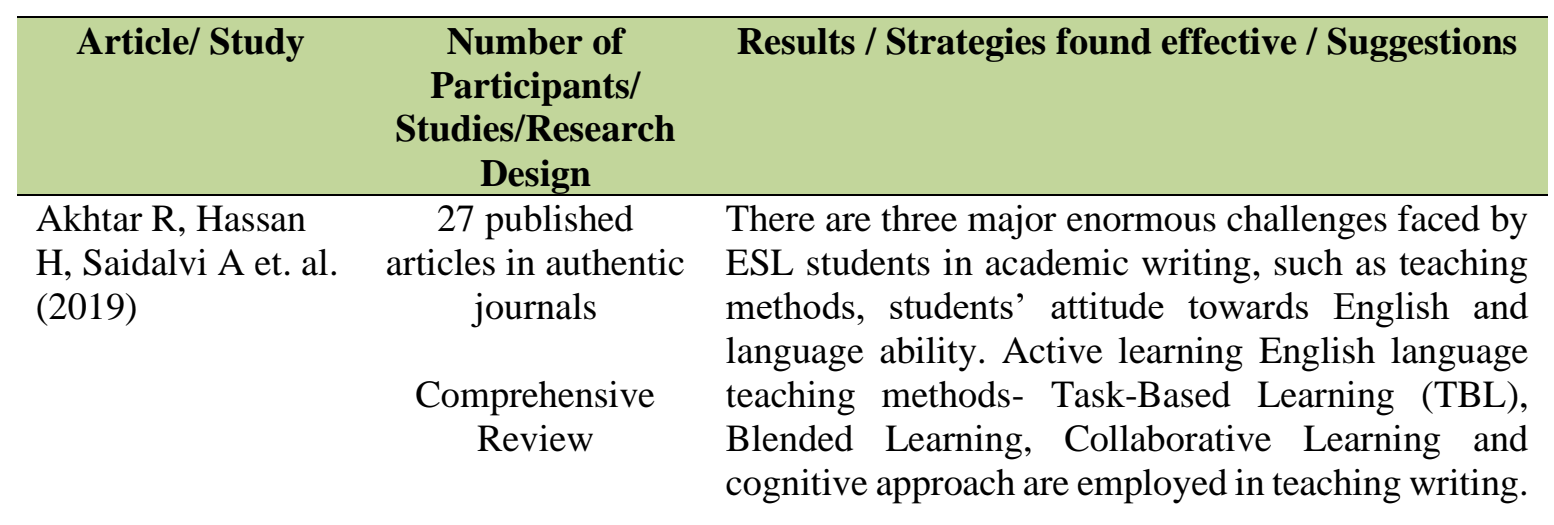

Table 3: Summary of systematic reviews on Approaches in Teaching Writing Skills

\begin{tabular}{|c|c|c|}
\hline Article/ Study & $\begin{array}{c}\text { Number of } \\
\text { Participants/ } \\
\text { Studies/ Research } \\
\text { Design }\end{array}$ & $\begin{array}{c}\text { Results / Strategies found effective / } \\
\text { Suggestions }\end{array}$ \\
\hline $\begin{array}{l}\text { Selvaraj \& Aziz } \\
(2019)\end{array}$ & $\begin{array}{c}18 \text { studies } \\
\text { Comprehensive } \\
\text { Review }\end{array}$ & $\begin{array}{l}\text { Process, genre, process genre, process product and } \\
\text { product based approaches are employed in ESL } \\
\text { classrooms. Process approach was employed } \\
\text { mostly in ESL teaching of writing in secondary } \\
\text { and tertiary level. Scaffolding, cooperative } \\
\text { learning and teacher and peer feedback help to } \\
\text { improve ESL students' writing. }\end{array}$ \\
\hline
\end{tabular}




\section{Discussion}

\section{Writing Challenges in ESL Classrooms}

Twelve studies were identified (Ghabool et al., 2012; Farooq et al., 2012; Whai et al., 2013; Whai et al., 2013; Al Badi, 2015; IM Alfaki, 2015; Pratiwi, 2016; Fareed et al., 2016; Singh et al., 2017; Ibnian, 2017; Habibi et al., 2017; Pablo \& Lasaten, 2018) on writing challenges faced by ESL students.

Ghabool and Kashef (2012) carried out a survey among 30 ESL students from upper and lower secondary. In this study, it has been identified that Malaysian ESL students face challenges in writing tasks particularly in language use (grammar) and punctuation. It is also evident that the written tasks show the interference of L1. Teachers' feedback were also taken into consideration to identify the challenges faced by the students.

Meanwhile, Farooq and Wahid (2012) aimed to explore writing difficulties in the English Language faced by ESL learners. This research was carried out among 245 college students. Writing is wide concept, so this study did not focus on all the aspects or issued related to this area. This study addressed only on writing difficulties such as vocabulary, L1 interference, spellings, grammar, rhetorical and punctuation. The outcome of the study showed students face challenges because of lack of vocabulary, L1 interference and grammatical structure. The researchers also stated that the writing difficulties faced by the students are interrelated. It was evident that the female students face more challenges in writing compared to the male students in this study.

In another research, Whai and Man (2013) selected 132 respondents for their study. The findings revealed these poly students faced difficulties in completing their writing tasks that required them to think creatively and critically. This was due to lack of vocabulary, L1 interference, tenses. These difficulties caused the poly students face challenges while proofreading their written tasks. They also had difficulties to differentiate between British and American English. The researchers believed these difficulties were due to lack of reading exposure in English.

In a survey by Whai and Yahya (2013) conducted at USM among 60 TESOL postgraduate students revealed that the students faced problems in relation to comprehension and conception of an idea, mechanics, composition, appropriate and accurate language, and vocabulary. This study employed both qualitative and quantitate method by using open-ended and close-ended questionnaires. Other writing difficulties were found out during the open-ended questionnaires which were lack of writing exercises, lack of interest in writing and time management. These students were also not exposed to a variety of writing tasks and formats. In addition, the students also face problem in getting appropriate writing samples for reference.

In another study conducted by IM Alfaki (2015), 20 samples essays from 20 students were selected to recognise the problems faced by the students in writing English. This research employed the descriptive research method which showed the students have various writing problems such as spelling, punctuation, and capitalisation. These problems were categorised into 4 main problems: mechanical, linguistics, cognitive and psychomotor namely.

Furthermore, another survey conducted by Al Badi (2015), 20 international students from four different nationalities were chosen as the respondents. The findings reveals the students face difficulties in language use, coherence and cohesion. This study also states that students' attitude is also another reason for them to face difficulty in writing.

Meanwhile, Pratiwi (2016), did a study on 79 students doing English Education Study Programme at University of Bengkulu. According to this research, the writing difficulties were varied according to the students" score. The difficulties were categorised into 3 categories - language use and vocabulary aspects (linguistics difficulty), the dominant one compared to organisations and mechanics aspects (cognitive difficulty) and content aspect (physiology difficult). Under linguistics difficulty, students face 
challenges in tenses, number, word order, and confused meaning. The students' vocabulary are limited and wrong choice of words.

In another research to identify ESL learners' problems in writing skills, Fareed et al. (2016) revealed through their study that 30 ESL undergraduate faced major problems which were lack of linguistic proficiency (grammar, syntax and vocabulary), writing anxiety, insufficient ideas, depending on L1 and poor structure organisation. They also ruled out that there were many factors causing these problems. They were untrained teachers, ineffective teaching approaches, low motivation, insufficient ideas, writing practice and reading habits.

In a case-study by Singh et al. (2017), sample essays from 144 students were gathered and studied using content analysis method. The findings showed two main errors made by students in writing which were subject-verb agreement and tenses. It was stated that the students over-generalised which caused them to use the tenses interchangeably. The other difficulties faced by students were complex structure construction. This dilemma was caused by students' inability to use Subject-verb agreement appropriately. These researches also commented that the students were committing these errors although they were at tertiary level because of poor command of English.

According to a survey done by Ibnian (2017) with 20 students using descriptive research method, it was evident that the students have various writing problems - morphology, syntax, usage errors, mechanical mistakes - spelling, punctuation, capitalization (spelling, tenses), preposition, connectors. It was revealed in this study that lack of clear assessment method and mark schemes and time restriction contributed to the writing difficulties faced by EFL learners. The teachers were lacking in adopting suitable teaching method and lending help in writing, lack of materials for consultation and inappropriate topic had caused difficulties for the students to engage in writing activities.

In a survey done by Habibi et al. (2017), a questionnaire was employed for 70 students. The finding concluded that there are 7 types of problems that students encounter in writing: poor organization/illogical sequence, words choice, grammatical error, spelling, confusion on supporting ideas, punctuation and capitalization. The findings also concluded that female students face problem in word choice whereas the male counterparts have problems in grammatical errors. Meanwhile, another research done by Pablo and Lasaten (2018) had identified that 227 students have difficulties such as lack of variety of ideas in terms of content and ideas, lack of connectives in terms of organization, incorrect word in terms of vocabulary, word choice, poor sentence structures in terms of language use and use of pronouns. In this research, the researchers found out that the students' essay quality ranges from poor to fair because of the difficulties they face in writing.

\section{Solutions to Overcome Writing Challenges in ESL Classrooms}

The above mentioned researches according to Table 1, had also suggested some solutions to overcome the challenges faced by students in writing in ESL classrooms. Ghabool et al. (2012) suggested that the students should be given more training on writing conventions. The teachers should explain to the students on the use of punctuation marks as it was a major difficulties in their study. Meanwhile Farooq et al. (2012) suggested teachers should adopt eclectic approach and teach vocabulary innovatively. Spelling activities should be given to the students. Teachers should emphasis more on grammar and written work than oral activity during English lesson. This was because writing is considered the most complex skill to be acquired.

Whai et al. (2013) believed extensive reading is needed to improve writing. More writing practices should be given to solve writing problems faced by students. . Different platforms such as blogs or daily journals can be used to encourage writing habit and enhance their proficiency level and improve their vocabulary. It was believed that these two skills (reading and writing) complements each other. In another study by Whai and Yahya (2013) reading extensively was suggested again as a method to improve writing skill. Guidance from the teachers on writing by giving feedbacks was also suggested by the researches. The feedbacks can be categorised into two, which are feedback on form and feedback 
on content. Another suggestion was peer review should be carried out in classrooms for the students to feel more confident.

In addition, IM Alfaki (2015) suggested that reading helps to increase knowledge on vocabulary, grammatical structures and keep the students informed. Giving free writing practice is also an effective method because it improves one's ability. Note taking is important in generating ideas. This will prevent the writers from having mental block. It is the teachers' duty to encourage the students to break the block in order to create creative and imaginative students. According to Al Badi (2015), teachers need to identify students' needs and difficulties first to tackle this problem. Students should also be taught the correct conventions of writing and strategies.

Pratiwi (2016) suggested that the students themselves need to increase their vocabulary. They should pay attention to tenses, vocabulary and punctuation. Meanwhile, the teachers are encouraged to give more exercises on writing and explain the language use itself. In addition, the study by Fareed et al. (2016) shed some light on remedial measures which are reading, vocabulary, writing practices, trained teachers, writing competitions and reformation of examination systems.

Another case-study by Singh et al. (2017), suggested that teachers give feedbacks after marking students' writing tasks. Students should also be encouraged to do corrections. Teacher should also incorporate grammar in writing lesson so that the grammatical items will make sense for the students understand better. The researchers believed that while doing process and product approach during writing lessons, students will eventually use grammar purposefully and while writing. In another similar study by Ibnian (2017), the research shed some insights both ESL learners and teachers to overcome the challenges in writing. The teachers should consider more emphasis on pre-writing stages such as brainstorming sessions, do some reading related to the topic, watching movies, listening activity or describing pictures on related topic to generate ideas. Teachers should also understand mark schemes and assessment instruments based on their teaching programme. Meanwhile students are suggested to train themselves to use mechanics of writing such as spelling, punctuation, quotation and capitalisation appropriately. They also should be given more adequate freedom and opportunity to select writing topic and ample time to gather ideas. Students should also practice different stages of writing process to improve their writing skills.

According to a study done by Habibi et al. (2017) among 70 students revealed there were 7 types of problems students encounter while writing. From this study, the researchers suggested solutions for both teachers and students too. Students need help from their lecturers regarding problems in writing. The lecturers should engage students with more interesting approaches and activities to avoid boredom during writing lesson. In another similar study by Pablo and Lasaten (2018), a descriptive qualitative research shed some lights by giving solutions to the students by referring to more writing samples which can be used as guidance. This will be a good exposure for them to follow the sample given. On the other hand, teachers can employ varieties of activities and drill constantly with identified difficulty.

\section{A Systematic Review on Challenges and Solutions on ESL Students' Academic Writing}

Table 2 shows a systematic review done by Akhtar et al. (2019). This review was done based on 27 published articles in the authentic journals. This study were separated into two categories where it involved ESL Malaysia students and non-Malaysians. The outcome of this review showed a wider context of challenges and factors influencing ESL students' writing skills. The findings revealed there are there are three major enormous challenges faced by ESL students in academic writing, such as teaching methods, students' attitude towards English and language ability. Active learning English language teaching methods - Task-Based Learning (TBL), Blended Learning, Collaborative Learning and cognitive approach are employed in teaching writing. This study also concluded that students should spend more time in developing their writing skills. 


\section{A Systematic Review on Approaches in Teaching Writing Skills}

A systematic review were carried out on the approaches in teaching writing skills in ESL classrooms. According to Table 3, 18 studies were selected for the comprehensive review. This review done by Selvaraj and Aziz (2019), was chosen to be included in this systematic review on challenges in ESL writing classrooms and solutions to overcome them because this review shed some light on suitable approaches, how writing instruction should be planned and some recommendation for improvement. This systematic review suggested that the most suitable approach in teaching writing skills at secondary and tertiary level is to employ process based approach. This is because adult student learners are matured, independent and have adequate knowledge in mastering the content and the language.

Teachers should know how to plan writing instruction in ESL classroom by knowing their students to determine their needs and proficiency level. Teachers should employ appropriate method in order to achieve their objectives during lesson. Moreover, teachers should also prepare suitable materials to cater their students' needs. Scaffolding plays a pivotal role in motivating students during lesson. This can be done by giving feedbacks or peer reviews to the students while writing task is conducted.

Some of the recommendations mentioned in this review for teachers particularly are combining suitable writing approaches for scaffolding because each process is believed to have its pro and cons. The researcher also recommended future research on wider options should be conducted especially on primary school students to ensure better writing skill is acquired from young age.

\section{Conclusion}

A total of 14 studies from the year 2012 to 2020 were identified for this systematic review in order to identify challenges in writing and solutions to overcome them. The studies were conducted mostly at tertiary level. Only one research was carried out in a secondary school in this review. Most of the studies identified challenges ESL learners encounter in ESL classrooms in carrying out writing tasks. Different types of research design and instruments were employed in these studies but the outcomes were almost similar. The challenges most of the learners were basically on word choice, vocabulary, grammar and poor organisation of ideas. These problems could be solved using the solutions given in most of the studies reviewed in this systematic review. These solutions are also recommendation for teachers in future to make writing lesson more interesting and motivates ESL learners. The most dominant suggestions are teachers as guidance assisting students in their writing tasks by giving feedbacks, provide sample essays for students to use as guide, more clear explanation on the task given and scaffolding. Teachers are also encouraged to use suitable approaches following students' needs. Meanwhile the students are encouraged to get used to mechanics of writing to improve their skills. Students should read extensively because reading complements writing activities. This will help students to acquire knowledge and help to generate ideas. Students should improve their vocabulary and grammar knowledge. Most of the studies conducted are at tertiary level. I believe measures should be taken at primary or secondary level to ensure students get a sound knowledge before entering tertiary level.

\section{References}

Ahmed, P.H. (2019). Major Writing Challenges Experienced by EFL Learners in Soran University. Journal of University of Human Development, 5(3), 120.

Akhtar, R. ... Hussain, S. (2019). A systematic review of the challenges and solutions of ESL students' academic writing. International Journal of Engineering and Advanced Technology, 8(5), 11691171.

Al-Gharabally, M. (2015). the Writing Difficulties Faced By L2 Learners and How To Minimize Them. International Journal of English Language and Linguistics Research, 3(5), 42-49.

Alfaki, I.M. (2015). University students' English writing problems. International Journal of English Language Teaching. Published by European Centre for Research Training and Development UK 
(Www.Eajournals.Org), 3(3), 40-52.

Anwar, M.N. \& Ahmed, N. (2016). Students' difficulties in learning writing skills in second language. Science International (Lahore), 28(4), 735-739.

Aragón, C. et al. (2013). An analysis of the writing skill difficulties of the english composition I students at the Foreign Language Department of the University of El Salvador. University of El Salvador 79.

Asiatefl. 2013 (1) English Challenges. (n.d.).

Basri, H. et al. (2019). Using Google Apps as Learning Strategy to Enhance ESL Writing. Creative Education, 10(2008), 2649-2657.

Boon, Y.M. et a. (2013). L2 writing challenges for the undergraduates: A performance analysis and a literature review on SIL domains. The Asian Conference on Language Learning Conference Proceedings 2013 302-316.

Christzer, J. et al. (2018). Writing Difficulties and Quality of Academic Essays of Senior High School Students. Asia Pacific Journal of Multidisciplinary Research, 6(4), 46-57.

Conference, I. \& Childhood, O.N.E. (2019). International conference on early childhood development (icecd 2019) 6.

Deane, P. (2018). The Challenges of Writing in School: Conceptualizing Writing Development Within a Sociocognitive Framework. Educational Psychologist, 53(4), 280-300.

Eng, I.J et al. (2016). International Journal of English Language , Literature and Translation Studies ( Ijelr ) Writing Problems Faced By the Secondary Level Students : a Study of the Kendrapada District 3: 36-41.

Fareed, M. et al. (2016a). ESL Learners' Writing Skills: Problems, Factors and Suggestions. Journal of Education \& Social Sciences, 4(2), 83-94.

Farooq, M.S. et al. (2012). Opinion of Second Language Learners about Writing Difficulties in English Language. South Asian Studies, 27(1), 183.

Gabrielatos, C. (2016). EFL Writing : Product and Process EFL Writing (December).

Ghabool, N. et al. (2012). Investigating Malaysian ESL Students' Writing Problems on Conventions, Punctuation, and Language Use at Secondary School Level. Journal of Studies in Education, 2(3), $130-143$.

Giridharan, B. (2012). Identifying Gaps in Academic Writing of ESL Students *. US-China Education Review A 6, 1548-6613.

Habibi, A. (2017). Students' Perception on Writing Problems: A Survey at One Islamic University in Jambi. Ta'dib, 22(1), 96-108.

Haynes, J. (2008). Language Learners Language Learners. Development 12(February 2004): 1399-1412.

Hodges, T.S. (2017). Theoretically Speaking: An Examination of Four Theories and How They Support Writing in the Classroom. The Clearing House: A Journal of Educational Strategies, Issues and Ideas, 90(4), 139-146.

Ibnian, S.S.K. (2017). Writing Difficulties Encountered by Jordanian EFL Learners. Asian Journal of Humanities and Social Studies, 5(03), 2321-2799.

Ien, L.K. et al. (2017). Overcoming Writing Problems Among Pupils In A Rural Primary School Sarawak. Jurnal Pendidikan Humaniora, 5(1), 1-7.

Jelas, Z.M. \& Dahan, H.M. (2010). Gender and educational performance: The Malaysian perspective. Procedia - Social and Behavioral Sciences, 7, 720-727.

Kho, M.G.W et al. (2013). Writing difficulties faced by Politeknik Kuching Sarawak commerce diploma students in doing their assignments. The Asian Journal of English Language \& Pedagogy, 1, 90101.

Larsen-Freeman, D. \& Long, M.H. (2014). An introduction to second language acquisition research. An Introduction to Second Language Acquisition Research, 1-398.

Li, K.L. \& Razali, A.B. (2019). Idea sharing: Process-based approach to writing in Malaysian english education. Pasaa, 58(12), 319-341.

Lowenfeld, B. (1963). Chapter III: The Visually Handicapped. Review of Educational Research, 33.

Maarof, N. \& Murat, M. (2013). Writing strategies used by ESL upper secondary school students. International Education Studies, 6(4), 47-55.

Md. Kamrul Hasan \& Mohd Moniruzzaman Akhand. (2010). Approaches to writing in EFL/ESL context: Balancing product and process in writing cass at tertiary level. Journal of NELTA, 15(1-2), 7788. 
Meiranti, R. (2012). Improving Students' Writing Skills Through Field Trip Method. English Review: Journal of English Education, 1(1), 1-8.

Mokhamar, N.W. (2016). The Impact of Integrating Reading and Writing Skills on Palestine Technical College Students' Paragraph Writing and Attitudes 192.

Moses, R.N. \& Mohamad, M. (2019). Challenges Faced by Students and Teachers on Writing Skills in ESL Contexts: A Literature Review. Creative Education, 10(13), 3385-3391.

Munawar, S. \& Chaudhary, A.H. (2019). Effect of Cooperative Learning on the Writing Skill at Elementary Level in the Subject of English. Bulletin of Education and Research, 41(3), 35-44.

Péwé, T.L et al. (1997). Eva Interglaciation forest bed, unglaciated East-Central Alaska: Global warming 125,000 years ago. Special Paper of the Geological Society of America, 319, 1-54.

Pratiwi, K. D. (2015). Students ' Difficulties in Writing English ( A Study at The Third Semester Students of English Education Program At University of Bengkulu Academic Year 2011-2012 )

Selvaraj, M. \& Aziz, A.A. (2019). Systematic Review: Approaches in Teaching Writing Skill in ESL Classrooms. International Journal of Academic Research in Progressive Education and Development, 8(4), 450-473.

Selvaraj, M. \& Aziz, A.A. (2020). Utilizing Flow Chart in Writing Narrative Essay: English as Second Language Students' Perceptions. International Journal of Academic Research in Business and Social Sciencesn, 10(3), 1-16.

Singh, C. K. S. et al. (2017). Grammar Errors Made by ESL Tertiary Students in Writing. English Language Teaching, 10(5), 16.

Solagha, O.Z. (2013). Writing Difficulties in the Swedish ESL-Classroom Writing Difficulties in the Swedish ESL-Classroom 1-25.

Sua, T.Y. (2007). Problems and Challenges of Learning Through a Second Language: the Case of Teaching of Science and Mathematics in English in the Malaysian Primary Schools. Kajian Malaysia, 25(2), 29-54.

Thevadas, S.A. \& Hashim, H. (2020). Improving Pupils' Descriptive Essay Writing Skills with The Use of Email Dialogue Journals. International Journal of Academic Research in Business and Social Sciences, 10(3), 698-722.

Thulasi, S et al. (2015). Role of model essays in developing students writing skills in Malaysian Schools: A review of literature. Mediterranean Journal of Social Sciences, 6(2S1), 56-61.

Wong, M.S.L. (2009). Language Anxiety and Motivation to Learn English: A Glimpse into the Form 4 Classroom. Online Submission (May): 1-15.

Yahya, M.Y. Bin. (2013). USM-PPIP TESOL Colloquium 2013, 25 May 2013 (Universiti Sains Malaysia) Writing Difficulties Faced by USM Postgraduate TESOL Students Marcus Kho Gee Whai Muhammad Yasir Bin Yahya. Writing Difficulties Faced by USM Postgraduate TESOL Students 2013(May).

Zahid Javid, C. \& Umer, M. (2014). Saudi Efl Learners' Writing Problems: a Move Towards Solution. The Global Summit on Education GSE 2014 2014(March): 4-5. 